\title{
THE DETERMINATION OF DRIVING CHARACTERISTICS OF HANOI BUS SYSTEM AND THEIR IMPACTS ON THE EMISSION
}

\author{
Nguyen Thi Yen Lien ${ }^{1,2}$, Nghiem Trung Dung ${ }^{1, *}$ \\ ${ }^{1}$ Hanoi University of Science and Technology, 1 Dai Co Viet, Hanoi \\ ${ }^{2}$ Hanoi University of Transport and Communication, 3 Cau Giay, Lang Thuong, Hanoi \\ "Email: dung.nghiemtrung@hust.edu.vn
}

Received: 2 June 2016; Accepted for publication: 25 October 2016

\begin{abstract}
A GPS with the update rate of $1 \mathrm{~Hz}$ was used to collect the real-world driving data of the five bus routes of Hanoi, namely No. 9, 18, 25, 32 and 33, on weekdays and weekend. GPS data were processed and used to simulate the emission by IVE model. The driving characteristics of Hanoi bus system and their impacts on the emission were determined. The obtained results show that the real-world driving characteristics are different for different bus routes and affect the emissions of vehicles. This paper, therefore, reconfirms the necessarity of the development of the typical driving cycle before conducting the emission inventory of mobile sources.

Keywords: driving behaviour, driving cycle, emission factor, Hanoi bus, IVE model.

\section{INTRODUCTION}

Motor vehicles are one of the main sources of air pollutants in big cities, especially in developing countries. The emission of a vehicle is dependent on several factors including the type and age of the vehicle, air pollution control technologies used, the type and quality of fuel, ambient air conditions and its operating conditions (cold-start, steady-state cruise, acceleration, deceleration and idle), etc. The emission of a vehicle can be measured under controlled conditions in the laboratory (engine and chassis dynamometer studies) with the use of a driving cycle which is built based on real-world activity data. The driving cycle represents the relationship between the instantaneous speed and time of a on-road vehicle in certain conditions. So, the driving cycle is dependent on the actual traffic conditions of each country, or its driving characteristics, meaning that, the driving cycle may vary from country to country, even from city to city [1]. This study is, therefore, aimed at the analysis of driving characteristics of Hanoi bus system and the assessment of their impacts on the emission.
\end{abstract}

\section{METHODOLOGY}

The methodology of this study is presented on Figure 1. 


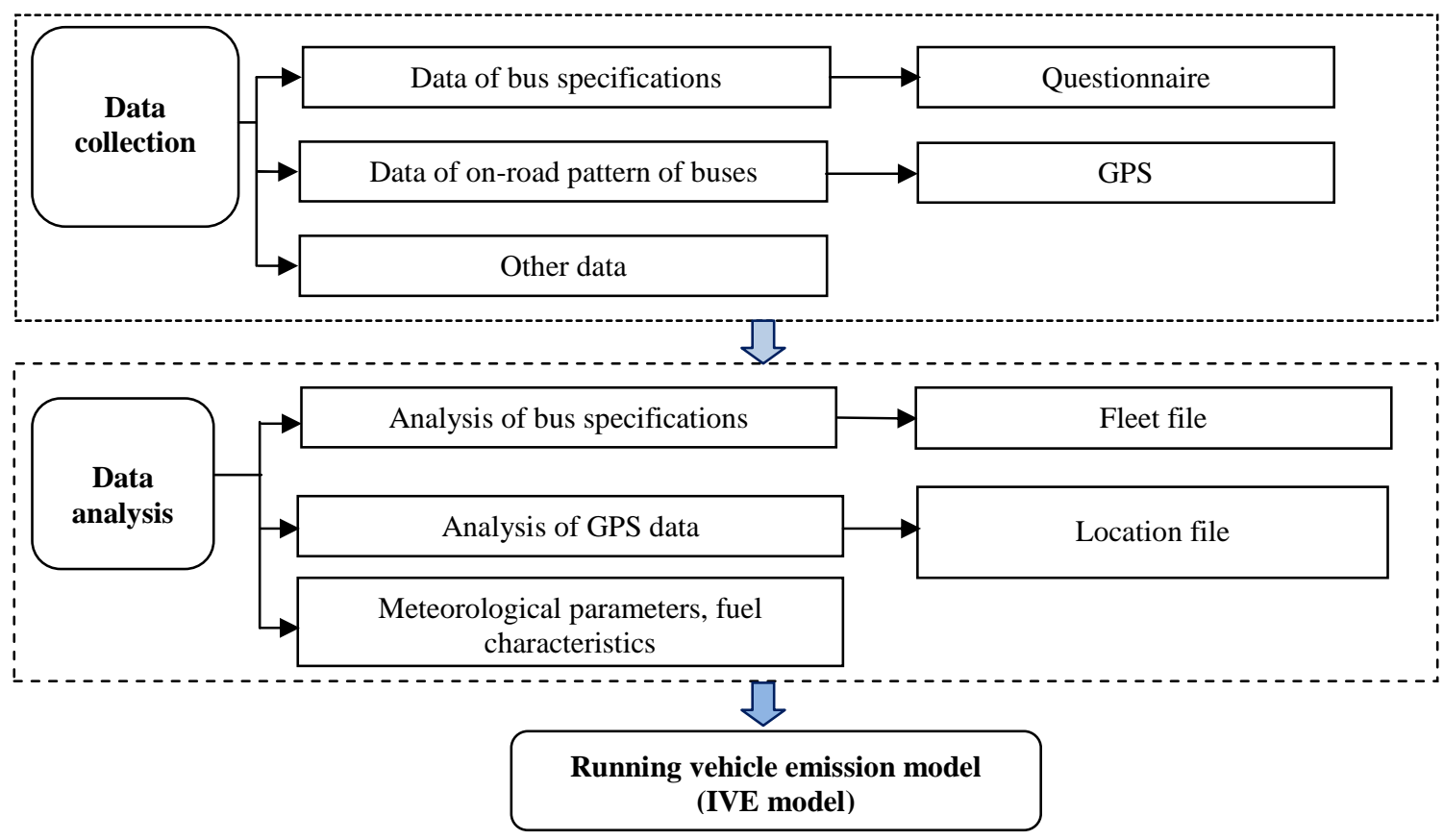

Figure 1. Framework of methodology.

\subsection{Data collection}

\subsubsection{Data of on-road pattern of buses}

Five bus routes shown in Table 1 were selected for this study. On each route, a bus was selected. A GPS, Garmin etrex vista HCx, was used to collect the data of on-road pattern of buses including cold-start, steady-state cruise, acceleration, deceleration, idle etc. The data were recorded on this bus, continuously from the starting point at around 6 am to the finishing point at around $8 \mathrm{pm}$, the same in weekdays and weekend.The data were recorded with the time step of one second to avoid losing information. These data were collected from July to October, 2015.

Table 1. The information of the five bus routes used in this study.

\begin{tabular}{|c|c|c|c|c|}
\hline Route & Type of route & Starting point & Finishing point & $\begin{array}{c}\text { No. of vehicles } \\
\text { per route }\end{array}$ \\
\hline 09 & \multirow{2}{*}{ Closed } & Hoan Kiem Lake & Hoan Kiem Lake & 18 \\
\cline { 3 - 5 } 18 & & $\begin{array}{c}\text { National Economics } \\
\text { University }\end{array}$ & $\begin{array}{c}\text { National Economics } \\
\text { University }\end{array}$ & 15 \\
\hline 32 & Radial & Giap Bat Coach Station & Nhon Transfer Station & 33 \\
\hline 25 & \multirow{2}{*}{ Ordinary } & Nam Thang Long Car Parking & Giap Bat Coach Station & 17 \\
\cline { 3 - 5 } & \multirow{2}{*}{ N3 } & My Dinh Coach Station & Xuan Dinh & 14 \\
\hline \multicolumn{2}{|c|}{ Note: ${ }^{(*)}$ Data were collected on Oct.25, 2015 from the website of Transerco (BUS-WEBGPS) } \\
\hline
\end{tabular}

\subsubsection{Data of bus specifications}


Data of bus specifications of Hanoi (the characteristics and age of vehicle, air pollution control technologies, the type and quality of fuel, etc.) were collected from the website of Transerco (BUS-WEBGPS) and by questionares. Number of questionnaires used was 100 ones.

\subsection{Data analysis}

MapSource software was used to convert data collected from GPS into Excel files, including two fields of data: time and speed. These data were used to:

\subsubsection{Determination of parameters reflecting real-world driving pattern}

A typical driving trip consists of different stages including idling, accelerating, cruising, and decelerating ones. The proportion of stages in different driving patterns is different and depends on the driver's behavior, the roadway type, and the level of traffic congestion [2]. The driving parameters for the characterization of a driving pattern is shown in Table 2.

Table 2. Driving parameters for the characterization of driving pattern [3-5].

\begin{tabular}{lcc}
\hline Parameters & Abbreviation & Unit \\
\hline Proportion of time accelerating $\left(\right.$ run with acceleration $\left.>0.1 \mathrm{~m} / \mathrm{s}^{2}\right)$ & $\mathrm{P}_{\mathrm{a}}$ & $\%$ \\
\hline Proportion of time decelerating $\left(\right.$ run with acceleration $\left.<-0.1 \mathrm{~m} / \mathrm{s}^{2}\right)$ & $\mathrm{P}_{\mathrm{d}}$ & $\%$ \\
\hline $\begin{array}{l}\text { Proportion of time cruising } \\
\left(-0.1 \mathrm{~m} / \mathrm{s}^{2} \leq \text { acceleration } \leq 0.1 \mathrm{~m} / \mathrm{s}^{2} \text { and average speed } \geq 5 \mathrm{~m} / \mathrm{s}\right)\end{array}$ & $\mathrm{P}_{\mathrm{c}}$ & $\%$ \\
\hline $\begin{array}{l}\text { Proportion of time creeping } \\
\left(-0.1 \mathrm{~m} / \mathrm{s}^{2} \leq \text { acceleration } \leq 0.1 \mathrm{~m} / \mathrm{s}^{2} \text { and average speed }<5 \mathrm{~m} / \mathrm{s}\right)\end{array}$ & $\mathrm{P}_{\mathrm{cr}}$ & $\%$ \\
\hline Proportion of time idling (speed $=0$ ) & $\mathrm{P}_{\mathrm{i}}$ & $\%$ \\
\hline Average speed of the entire driving cycle & $\mathrm{V}_{1}$ & $\mathrm{~km} / \mathrm{h}$ \\
\hline Average running speed & $\mathrm{V}_{2}$ & $\mathrm{~km} / \mathrm{h}$ \\
\hline Maximum speed & $\mathrm{V}_{\max }$ & $\mathrm{km} / \mathrm{h}$ \\
\hline Standard deviation of speed & $\mathrm{V}_{\mathrm{sd}}$ & $\mathrm{km} / \mathrm{h}$ \\
\hline Average acceleration of all acceleration phases & $\bar{a}_{\text {pas }}$ & $\mathrm{m} / \mathrm{s}^{2}$ \\
\hline Average deceleration of all deceleration phases & $\bar{a}_{\text {nasg }}$ & $\mathrm{m} / \mathrm{s}^{2}$ \\
\hline Root mean square of acceleration & $\mathrm{RMSA}$ & $\mathrm{m} / \mathrm{s}^{2}$ \\
\hline Average over all positive Vehicle Specific Power & $\overline{V S P}_{\text {pas }}$ & $\mathrm{W} / \mathrm{kg}$ \\
\hline Average over all negative Vehicle Specific Power & $\overline{V S P}_{\text {nasg }}$ & $\mathrm{W} / \mathrm{kg}$ \\
\hline Positive kinetic energy & $\mathrm{PKE}$ & $\mathrm{m} / \mathrm{s}^{2}$ \\
\hline
\end{tabular}

The positive kinetic energy (PKE) is estimated as follows:

$$
\text { PKE }=\frac{1}{\text { Dist }} \sum_{i=2}^{n} \begin{cases}v_{i}^{2}-v_{i-1}^{2} & \left(v_{i}>v_{i-1}\right) \\ 0 & (\text { else })\end{cases}
$$

where Dist is the length of a trip (m), $\mathrm{n}$ is the total number of data points in the trip, and $\mathrm{v}$ is the speed $(\mathrm{m} / \mathrm{s})$.

$\mathrm{SAFD}_{\text {diff }}$ is used to compare the difference in the driving characteristics between the bus routes. It represents the difference in speed-acceleration-frequency distribution (SAFD) of different driving cycles. The following equation is used to calculate $\mathrm{SAFD}_{\text {diff }}$ in our study $[6,7]$ : 


$$
\mathrm{SAFD}_{\text {diff }}=\frac{\sum_{\mathrm{i}}\left(\operatorname{SAFD}_{\text {tuyen1 }}(\mathrm{i})-\mathrm{SAFD}_{\text {tuyen 2 }}(\mathrm{i})\right)^{2}}{\sum_{\mathrm{i}}\left(\mathrm{SAFD}_{\text {tuyen } 2}(\mathrm{i})\right)^{2}} \times 100
$$

where $\mathrm{i}$ is the $i^{\text {th }}$ bin in the SAFD.

\subsubsection{Emission calculation}

IVE (International Vehicle Emissions) model was used to simulate the vehicle emission based on the processed GPS data. The IVE model was developed by the US Environmental Protection Agency (US.EPA). This model is used to estimate the quantities of air pollutants emitted from vehicles. It was designed specifically to be able to meet flexible needs of developing countries in an effort to determine gas emissions from mobile sources. The precision of the IVE model was evaluated by Guo Hui et al. and the results demonstrated a good agreement between the IVE model and on-road optical remote sensing measurement (all the correlation coefficients, $\mathrm{r}^{2}$, between emission factors obtained by the former and the later were above 0.8$)$ [8]. model:

The processed GPS data were used to determine two very important parameters in the IVE

+ VSP (Vehicle Specific Power) is defined as a power per unit mass to overcome road grade, rolling and aerodynamic resistance, and inertial acceleration. Equation 3 is the initial equation for VSP [9]:

$$
\mathrm{VSP}(\mathrm{kW} / \text { ton })=\mathrm{v} \times[1.1 \times \mathrm{a}+9.81(\arctan (\sin (\text { grade })))+0.132]+0.000302 \times \mathrm{v}^{3}
$$

where: a - acceleration $\left(\mathrm{m}^{2} / \mathrm{s}\right) ; \mathrm{v}$ - speed $(\mathrm{m} / \mathrm{s})$; grade - road grade (radian)

+ ES (Engine stress) is the parameter correlating the vehicle power load experienced over the past 20 seconds of operation, from $\mathrm{t}=-5$ to $-25 \mathrm{sec}$, and the implemented RPM (Revolution Per Minute) of the engine. The Engine stress is calculated using Equation 4 [9]:

$$
\text { ES }(\text { unitless })=\text { RPMIndex }+(0.08 \text { ton } / \mathrm{kW}) \times \text { PreaveragePower }
$$

where: PreaveragePower $=$ Average $\left(\mathrm{VSP}_{\mathrm{t}=-5}\right.$ to $\left.-25 \mathrm{sec}\right)(\mathrm{kW} /$ ton $)$.

RPMIndex $=$ Speed $_{t=0} /$ SpeedDivider (unitless).

\section{RESULTS AND DISCUSSIONS}

\subsection{Parameters of driving behavior}

15 typical parameters of the real-world driving behavior of Hanoi bus system are determined and presented in Table 3.

It can be seen from Table 3 that the values of the same parameter of the driving behavior for different bus routes can be considered to be relatively even. They are not much change in the comparison with those reported by Trang et. al. in 2011 [10] for the bus routes No. 18 and 30. The comparison with the bus operation in Braunschweig city, Germany and the European Transient Cycle (ETC) - part1 (test cycle) shows that the average speed of buses working in Hanoi is slower, the proportion of time cruising $(\mathrm{Pc})$ is smaller than those of ETC-part1 and Braunschweig city driving cycle. 
Table 3. Driving characteristics of selected Hanoi bus routes.

\begin{tabular}{|c|c|c|c|c|c|c|c|c|c|}
\hline \multirow{2}{*}{ Parameter } & \multirow{2}{*}{ Unit } & \multicolumn{5}{|c|}{ The routes in this study } & \multirow{2}{*}{$\begin{array}{l}\text { Trang } \\
\text { et. al. }{ }^{(a)} \\
{[10]}\end{array}$} & \multirow{2}{*}{$\begin{array}{c}\text { Braunschweig } \\
\text { city, Germany } \\
\text { [3] }\end{array}$} & \multirow{2}{*}{$\begin{array}{c}\text { ETC- } \\
\text { part } 1 \\
{[3]}\end{array}$} \\
\hline & & 09 & 18 & 25 & 32 & 33 & & & \\
\hline $\mathrm{V}_{1}$ & $\mathrm{~km} / \mathrm{h}$ & 13.90 & 13.01 & 16.54 & 15.74 & 15.01 & 13.02 & 22.6 & 23.25 \\
\hline $\mathrm{V}_{2}$ & $\mathrm{~km} / \mathrm{h}$ & 15.90 & 15.54 & 18.57 & 18.26 & 17.58 & 15.71 & 27.3 & 23.3 \\
\hline $\mathrm{V}_{\max }$ & $\mathrm{km} / \mathrm{h}$ & 58.75 & 49.75 & 55.25 & 79.25 & 51.00 & 39.75 & 58.21 & 50 \\
\hline $\mathrm{V}_{\mathrm{sd}}$ & $\mathrm{km} / \mathrm{h}$ & 11.09 & 10.77 & 11.93 & 11.12 & 11.67 & 8.30 & 16.61 & 13.27 \\
\hline $\mathrm{P}_{\mathrm{a}}$ & $\%$ & 33.60 & 32.29 & 34.56 & 34.04 & 32.54 & 36.22 & 40.92 & 40.83 \\
\hline $\mathrm{P}_{\mathrm{d}}$ & $\%$ & 35.72 & 32.93 & 33.97 & 33.87 & 31.60 & 35.15 & 28.45 & 32.00 \\
\hline $\mathrm{P}_{\mathrm{c}}$ & $\%$ & 4.78 & 5.49 & 8.75 & 9.27 & 9.26 & 6.16 & 14.08 & 21.17 \\
\hline $\mathrm{P}_{\mathrm{Cr}}$ & $\%$ & 13.88 & 14.24 & 12.05 & 10.01 & 12.40 & 12.45 & - & - \\
\hline $\mathrm{P}_{\mathrm{i}}$ & $\%$ & 12.02 & 15.05 & 10.67 & 12.81 & 14.20 & 10.02 & 16.55 & 0.00 \\
\hline $\bar{a}_{\text {pas }}$ & $\mathrm{m} / \mathrm{s}^{2}$ & 1.06 & 0.89 & 0.74 & 0.72 & 0.71 & 0.31 & 0.424 & 0.27 \\
\hline $\bar{a}_{n E g}$ & $\mathrm{~m} / \mathrm{s}^{2}$ & -1.00 & -0.88 & -0.75 & -0.73 & -0.73 & -0.31 & -0.595 & -0.31 \\
\hline RMSA & $\mathrm{m} / \mathrm{s}^{2}$ & 1.34 & 1.09 & 0.92 & 0.95 & 0.88 & 0.40 & 0.251 & 0.15 \\
\hline$\overline{V S P}_{p a s}$ & $\mathrm{~W} / \mathrm{kg}$ & 4.01 & 2.98 & 3.01 & 2.71 & 2.48 & 1.20 & - & - \\
\hline$\overline{V S P}_{\mathrm{neg}}$ & $\mathrm{W} / \mathrm{kg}$ & -6.16 & -5.06 & -4.59 & -4.20 & -4.19 & -1.17 & - & - \\
\hline PKE & $\mathrm{m} / \mathrm{s}^{2}$ & 0.67 & 0.55 & 0.43 & 0.40 & 0.40 & 0.25 & 5.560 & 3.53 \\
\hline \multicolumn{10}{|c|}{ Note: ${ }^{(a)}$ The average values of the bus routes No. 18 and 30 of Hanoi in 2011.} \\
\hline
\end{tabular}

The speed-acceleration-frequency distribution plots of the entire recorded data are compared with ETC-part1as shown on Figure 2.

It can be seen from Figure 2 that SAFDs of the five bus routes are quite similar but significantly different from that of ETC-part1. SAFDs of the five bus routes in Hanoi contain less number of high-speed values but higher number of almost zero-speed values than those of ETC-part1. Therefore, the proportions of time idling and creeping in Hanoi are higher. And the proportion of time cruising with the speed in the range of $30-50 \mathrm{~km} / \mathrm{h}$ of Hanoi buses is smaller than that of ETC-part1. These results, therefore, are reasonable and reflect the real conditions of the transport system in Hanoi, where the intersections of roads are mainly in the same level and traffic jams are frequently happened. For the bus route of No. 32, because a part of this route is located in the suburb of the city, thus, its SAFD has the smaller number of zero-speed values $\left(\mathrm{FD}_{\mathrm{v}=0}<0.1\right)$ than those of the remaining routes.

In addition, there are certain differences of driving features between the weekend and the weekdays as assessed by SAFD and shown in Table 4. Also, due to the reason mentioned above, exceeding the speed limit $\left(\mathrm{V}_{\max }>60 \mathrm{~km} / \mathrm{h}\right)$ is normally happened on the bus route No.32 at the weekend resulting in that this route has the highest value of $\mathrm{SAFD}_{\text {diff. }}$ 

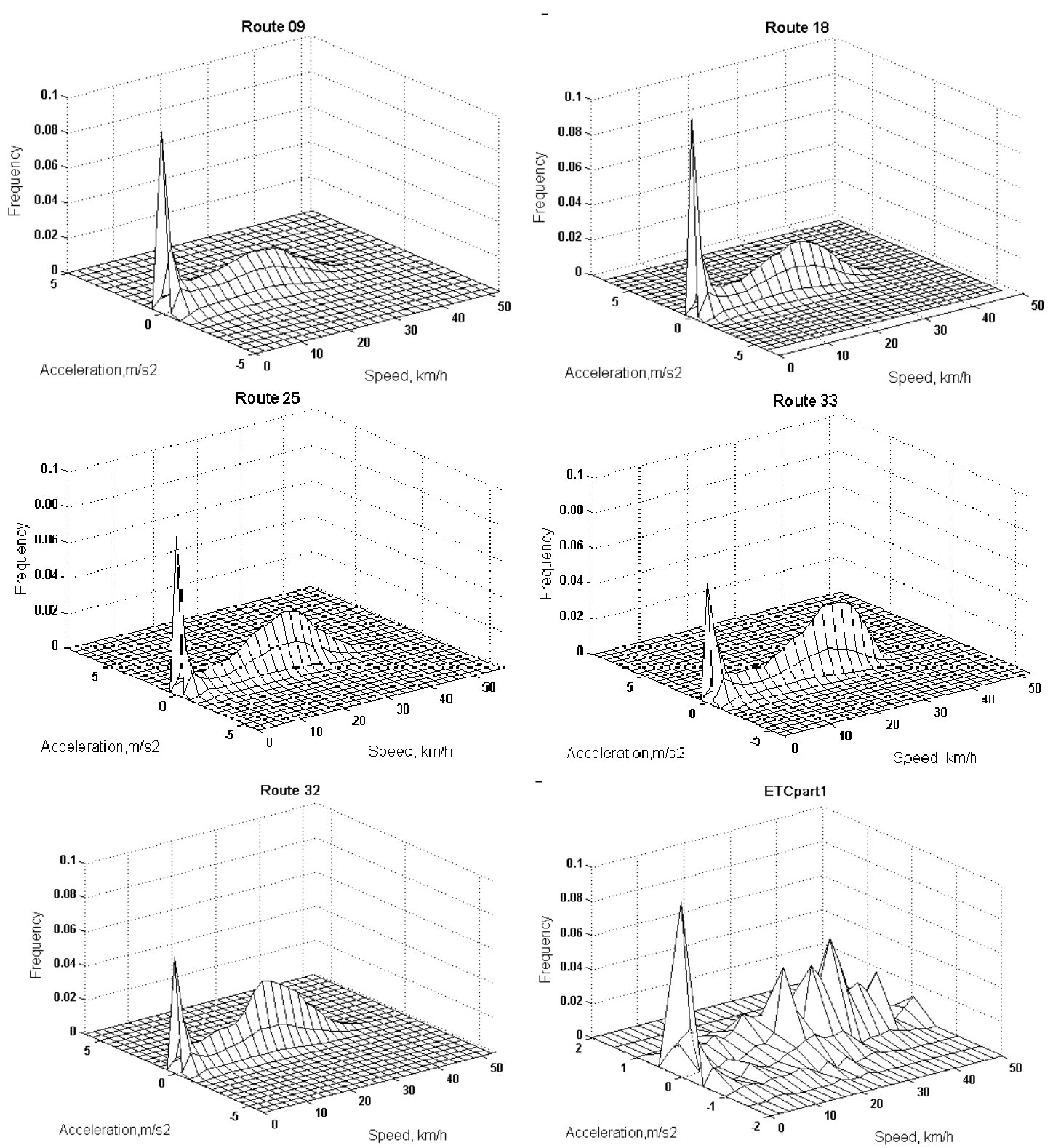

Figure 2. Speed-acceleration-frequency distribution plots of the five bus routes in Hanoi and ETC-part1.

Table 4. SAFD differences between the weekend and weekdays.

\begin{tabular}{|l|c|c|c|c|c|}
\hline & Route 09 & Route 18 & Route 25 & Route 32 & Route 33 \\
\hline SAFD $_{\text {diff }}(\%)$ & 3.9 & 0.8 & 0.8 & 11.7 & 5.6 \\
\hline
\end{tabular}

\subsection{Emission factors of different driving characteristics}

In order to estimate the impact of the driving cycles on the vehicle emissions, the IVE model was applied to simulate the vehicle emissions for the bus routes of different driving characteristics, but with the same vehicle type, fuel type and meteorological conditions. The 
emission factor in the running mode $\left(\mathrm{EF}_{\text {running }}\right)$ is used in this study. The $\mathrm{EF}_{\text {running }}$ was determined for different driving characteristics including the data collected on the five selected bus routes, the activity data of Hanoi bus in 2011 [10], and the speed - time data of ETC-part 1 test cycle. The obtained results are shown in Table 5.

Table 5. $\mathrm{EF}_{\text {running }}$ of different driving characteristics.

\begin{tabular}{|c|c|c|c|c|c|c|c|}
\hline \multirow{2}{*}{$\begin{array}{c}\text { Driving } \\
\text { characteristics }\end{array}$} & \multicolumn{7}{|c|}{$\mathrm{EF}_{\text {running }}(\mathrm{g} / \mathrm{km})$} \\
\cline { 2 - 8 } & $\mathrm{CO}$ & $\mathrm{VOC}$ & $\mathrm{NO}_{\mathrm{x}}(\mathrm{as} \mathrm{N})$ & $\mathrm{SO}_{2}$ & $\mathrm{PM}$ & $\mathrm{N}_{2} \mathrm{O}$ & $\mathrm{CO}_{2}$ \\
\hline Route 09 & 3.50 & 1.16 & 18.25 & 0.145 & 2.82 & 0.013 & 1422 \\
\hline Route 18 & 5.90 & 2.10 & 30.60 & 0.235 & 4.75 & 0.022 & 2302 \\
\hline Route 25 & 2.90 & 0.98 & 14.93 & 0.120 & 2.33 & 0.011 & 1175 \\
\hline Route 32 & 2.96 & 1.02 & 15.25 & 0.121 & 2.38 & 0.011 & 1185 \\
\hline Route 33 & 3.15 & 1.08 & 16.25 & 0.13 & 2.54 & 0.012 & 1273 \\
\hline Trang et. al. [10] & 3.47 & 0.83 & 26.91 & 0.120 & 7.69 & 0.01 & 1202 \\
\hline ETC-part1 [3] & 1.98 & 0.68 & 10.1 & 0.008 & 1.59 & 0.008 & 805 \\
\hline
\end{tabular}

As can be seen in Table 5, for the same vehicle fleet, fuel and meteorological conditions, the emission factors are dependent on the real-world driving characteristics. It is worthy to note that, the emission factors, $\mathrm{EF}_{\text {running, }}$ obtained in this study for the five selected bus routes are similar with those of Trang et al. [10] but different (e.g., up to $41 \%$ with VOC) from those of the ETC-part1 test cycle.

\subsection{Effects of the driving characteristics on the vehicle emissions}

The correlation coefficients, $\mathrm{r}^{2}$, between the $\mathrm{EF}_{\text {running }}$ and the typical parameters are calculated based on the Matlab software. The typical parameters of the driving behavior that have the highest effect on the vehicle emissions are shown in Table 6. For parameters that are not presented in Table 6, their relationships with the $\mathrm{EF}_{\text {running }}$ are lower or negligible.

Table 6. Correlation coefficients between the $\mathrm{EF}_{\text {running }}$ and the typical parameters.

\begin{tabular}{|c|c|c|c|c|c|c|c|c|}
\hline \multirow{2}{*}{ Parameter } & \multicolumn{7}{|c|}{ The $\mathrm{EF}_{\text {running }}$ of the pollutants } & \multirow{2}{*}{$\begin{array}{c}\text { Degree of } \\
\text { correlation }\end{array}$} \\
\cline { 2 - 9 } & $\mathrm{CO}$ & $\mathrm{VOC}$ & $\mathrm{NO}_{\mathrm{X}}($ as N) & $\mathrm{SO}_{2}$ & $\mathrm{PM}$ & $\mathrm{CO}_{2}$ & $\mathrm{~N}_{2} \mathrm{O}$ & High \\
\hline $\mathrm{V}_{1}$ & 0.70 & 0.68 & 0.71 & 0.72 & 0.70 & 0.72 & 0.72 & High \\
\hline $\mathrm{V}_{2}$ & 0.76 & 0.74 & 0.77 & 0.77 & 0.76 & 0.77 & 0.77 & High \\
\hline $\mathrm{P}_{\mathrm{Cr}}$ & 0.75 & 0.74 & 0.75 & 0.75 & 0.75 & 0.75 & 0.75 & Medium \\
\hline $\mathrm{P}_{\mathrm{c}}$ & 0.46 & 0.43 & 0.47 & 0.48 & 0.46 & 0.48 & 0.48 & (n) \\
\hline
\end{tabular}

For all the pollutants shown in Table 6, the correlation coefficients of their $\mathrm{EF}_{\text {running }}$ with $\mathrm{V}_{2}$ are always higher than those with $\mathrm{V}_{1}$. Please note that the $\mathrm{EF}$ used in this study is the $\mathrm{EF}_{\text {running, }}$, i.e., for running mode $(v \neq 0)$ of the bus. $V_{2}$ is the average running speed (meaning that representing for running mode) while $\mathrm{V}_{1}$ is the average speed of the entire driving cycle including idling mode $(\mathrm{v}=0)$. Consequently, the $\mathrm{EF}_{\text {running }}$ depends on $\mathrm{V}_{2}$ more than $\mathrm{V}_{1}$, resulting in the above result. 
The correlation coefficients of their $\mathrm{EF}_{\text {running }}$ with $\mathrm{P}_{\mathrm{cr}}$ are also higher than those with $\mathrm{P}_{c}$, meaning that the effect of $\mathrm{P}_{\mathrm{Cr}}$ on $\mathrm{EF}_{\text {running }}$ is stronger than that of $\mathrm{P}_{\mathrm{c}}$. This can be explained by the fact that the proportions of time creeping $\left(\mathrm{P}_{\mathrm{Cr}}\right)$ of all the driving cycles are higher than those of time cruising $\left(\mathrm{P}_{\mathrm{c}}\right)$. And, obviously, the emission of the vehicle in the creeping mode $(\mathrm{V}<5 \mathrm{~m} / \mathrm{s})$ is higher than that of the cruising mode [2].

The differences of the driving characteristics on the five bus routes for $\mathrm{V}_{1}, \mathrm{~V}_{2}, \mathrm{P}_{\mathrm{c}}$, and $\mathrm{P}_{\mathrm{Cr}}$ are $10 \%, 8 \%, 31 \%$, and $16 \%$ respectively. In the comparison with ETC-part1, the differences of these parameters are much higher: $23 \%\left(\mathrm{~V}_{1}\right), 15 \%\left(\mathrm{~V}_{2}\right)$ and $60 \%(\mathrm{Pc})$. Therefore, there are relatively large differences for the four parameters that strongly affect $\mathrm{EF}_{\text {running }}$ as indicated in Table 7.

Table 7. Average differences of the emission factors between different driving characteristics.

\begin{tabular}{|c|c|c|c|c|c|c|c|c|}
\hline \multirow{2}{*}{\multicolumn{2}{|c|}{ Comparison }} & \multicolumn{7}{|c|}{ Average differences of the $\mathrm{EF}_{\text {running }}(\%)$} \\
\hline & & $\mathrm{CO}$ & VOC & $\mathrm{NO}_{\mathrm{x}}($ as $\mathrm{N})$ & $\mathrm{SO}_{2}$ & PM & $\mathrm{N}_{2} \mathrm{O}$ & $\mathrm{CO}_{2}$ \\
\hline \multirow{2}{*}{ 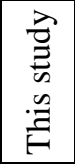 } & $\begin{array}{l}\text { Between different routes of the five } \\
\text { selected bus ones of Hanoi }\end{array}$ & 34 & 37 & 35 & 32 & 34 & 32 & 32 \\
\hline & $\begin{array}{l}\text { Between the average of five selected bus } \\
\text { routes of Hanoi and ETC-part1 }\end{array}$ & 39 & 41 & 40 & 38 & 39 & 33 & 37 \\
\hline \multirow{2}{*}{\multicolumn{2}{|c|}{ 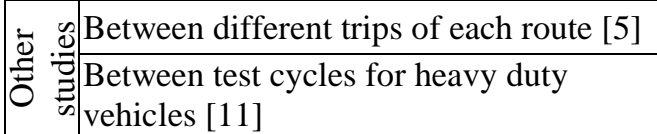 }} & 51 & 32 & 76 & - & - & - & 20 \\
\hline & & - & - & $33^{(\mathrm{a})}$ & - & $\begin{array}{l}19^{(\mathrm{b})} \\
41^{(\mathrm{c})}\end{array}$ & - & - \\
\hline
\end{tabular}

In summary, the values of the $\mathrm{EF}_{\text {running }}$ largely vary when the same vehicle is simulated by different driving characteristics. The difference of the $\mathrm{EF}_{\text {running }}$ between Hanoi bus routes can be up to $37 \%$ (with VOC). And, the difference of the $\mathrm{EF}_{\text {running }}$ between Hanoi and ETC-part1 is higher, and can be up to $41 \%$. This can be explained by the high difference between the same typical parameters of different driving characteristics. And the difference of between Hanoi buses and ETC-part1 is higher (up to $60 \%$ for $\mathrm{P}_{\mathrm{c}}$ ). This point is also reported by Zhai et al. [5], where, the difference can be up to $76 \%$. Figure 4 shows the amount of pollutants emitted as a function of the driving cycles.

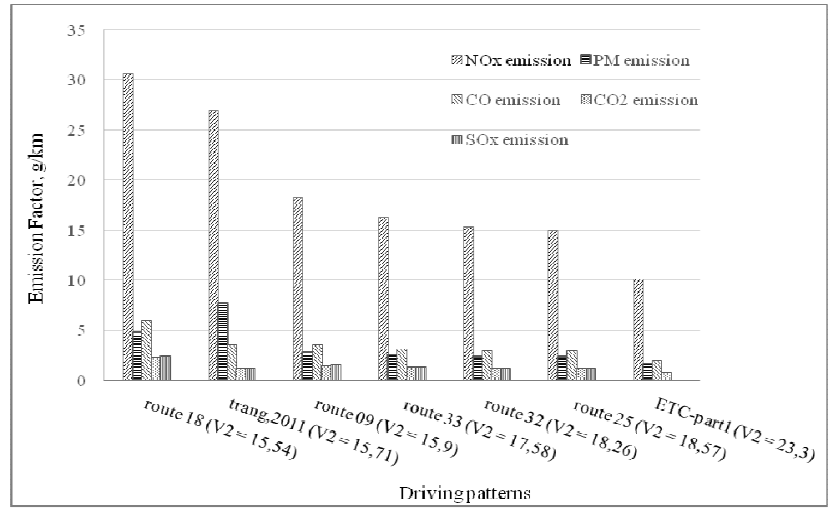

Figure 4. The distribution of the emission as a function of the driving cycles $\left(\mathrm{EF}_{\mathrm{CO} 2} \times 10^{-3}, \mathrm{EF}_{\mathrm{SO} 2} \times 10\right)$. 
It can be seen from Figure 4 that, the average speed of a driving cycle strongly affects the vehicle emission, therefore, almost the emission models for on-road vehicles are developed based on the average speed. In the range of speed from $15.5 \mathrm{~km} / \mathrm{h}$ to $23.3 \mathrm{~km} / \mathrm{h}$ on Figure 4, the emission is decreased when the speed is increased. This result is similar to that reported by Matthew [12] and David et al. [13]. And, as anticipated, the simulated emission factors, which are based on the driving characteristics of the selected bus routes in Hanoi, are usually higher than those of the test cycles of ETC-part1. This is nothing strange as the traffic conditions in Hanoi are worse in Europe resulting in lower speed, smaller proportion of time cruising with average speed $v>5 \mathrm{~m} / \mathrm{s}$, etc.

\section{CONCLUSIONS}

Typical parameters of the driving behavior of the five bus routes in Hanoi are determined. It is found that four parameters that have the highest impact on $\mathrm{EF}_{\text {running }}$ are $\mathrm{V}_{1}, \mathrm{~V}_{2}, \mathrm{P}_{\mathrm{Cr}}$, and $\mathrm{P}_{\mathrm{c}}$, of which, the average running speed $\left(\mathrm{V}_{2}\right)$ is the most important one. This study also reconfirm that the real-world driving characteristics strongly impact on the emission factors of the vehicles and that these characteristics clearly differ from one area to another, even within the same city. Therefore, the emission factors of motor vehicles must be determined based on the driving characteristics of local traffic conditions. In other words, the application of the test cycles from other countries for the determination of the emissions in Vietnam may produce erroneous results. In addition, this study confirms that vehicle emission models, that are based on the average speed only, do not fully reflect the emission characteristics of real-world vehicles because the emission factors of the vehicle depend on not only the average speed but also many other typical parameters. This paper also indicates that the driving behavior plays a very important role in the reduction of vehicle emissions.

\section{REFERENCES}

1. Tong H.Y, Hung W.T - A Framework for Developing Driving Cycles with On-Road Driving Data, Transport Reviews: A Transnational Transdisciplinary Journal 30 (5) (2010) 589-615.

2. Mathew Barth, Kanok Boriboonsomsin - Traffic congestion and greenhouse gases, The Regents of the University of California (2009).

3. Barlow T. J ., Latham S ., McCrae I.S ., Boulter P. G. - A reference book of driving cycles for use in the measurement of road vehicle emissions, Published Project Report PPR354. TRL limited., 2009.

4. Shuming Shi, Guilin Zou, Li Liu, Hailin Kui, Di Wu - Study on the Fuzzy Clustering Method of the Microtrips for Passenger Car Driving Cycle in Changchun,Vehicle Power and Propulsion Conferenc. VPPC '09. IEEE, 2009.

5. Haibo Zhai, H. Christopher Frey, Nagui M. Rouphail - A Vehicle Specific Power Approach to Speed- and Facility- Specific Emissions Estimates for Diesel Transit Buses, Environmental Science \& Technology 42 (21) (2008) 7985-7991.

6. Ali Ashtari, Eric Bibeau,Soheil Shahidinejad - Using Large Driving Record Samples and a Stochastic Approach for Real-World Driving Cycle Construction: Winnipeg Driving Cycle Transportation Science 48 (2) (2014) 170 - 183. 
7. John Brady, Margaret O'mahony - The development of a driving cycle for the greater Dublin area using a large database of driving data with a stochastic and statistical methodology, Proceedings of the ITRN2013 (2013).

8. Guo Hui, Zhang Qing-Yu, Shi Yao,Wang Da-Hui - Evaluation of the International Vehicle Emission (IVE) model with on-road remote sensing measurements, Journal of environmental sciences (China) 19 (2007) 818-826.

9. International Sustainable Systems Research Center (ISSRC) - IVE Model Users Manual Version 2.0 www.issrc.org/ive (2008).

10. Nguyen Thu Trang, Nghiem Trung Dung, Tran Thu Trang - Potentiality of Co-benefits of climate and air quality in fuel switching for Hanoi bus system, Journal of Science and Technology 49 (4) (2011) 117-128.

11. Efthimios Zervas, George Bikas - Impact of the Driving Cycle on the NOx and Particulate Matter Exhaust Emissions of Diesel Passenger Cars, Energy \& Fuels 22 (2008) 17071713.

12. Matthew Barth - Analysis of GPS-Based Vehicle Activity Data and their Impact on $\mathrm{CO}_{2}$ Emissions, College of Engineering-Center for Environmental Research and Technology University of California-Riverside, 2008.

13. David Williams, Robin North - An evaluation of the estimated impacts on vehicle emissions of a 20mph speed restriction in central London - Transport and Environmental Analysis Group, Centre for Transport Studies Imperial College London, 2013.

\title{
TÓM TÁ̀T
}

\section{XÁC ĐỊNH ĐẶC TRƯNG LÁI CỦA HÊ THỐNG XE BUÝT HÀ NỘI VÀ TÁC ĐỘNG CỦA CHÚNG TỚI SỰ PHÁT THẢI}

\author{
Nguyễn Thị Yến Liên ${ }^{1,2}$, Nghiêm Trung Dũng ${ }^{1, *}$ \\ ${ }^{1}$ Trường Đại học Bách khoa Hà Nội, số 1 Đại Cồ Việt, Hà Nội \\ ${ }^{2}$ Trường Đại học Giao thông Vận tải, số 3 Cầu Giấy, Láng Thương, Hà Nội \\ "Email: dung.nghiemtrung@hust.edu.vn
}

Đã tiến hành thu thập dữ liệu lái thực tế của 5 tuyến xe buýt tại Hà Nội có số hiệu là 09,18 , 25,32 và 33 , trong các ngày làm việc và ngày nghỉ cuối tuần bằng thiết bị GPS có tốc độ cập nhật $1 \mathrm{~Hz}$. Dữ liệu GPS đã được xử lí và sử dụng để mô phỏng nồng độ khí phát thải bằng phần mềm IVE. Đặc trưng lái của hệ thống xe buýt Hà Nội và các tác động của nó lên sự phát thải khí đã được xác định. Các kết quả đạt được cho thấy đặc trưng lái thực tế giữa các khu vực khác nhau là khác nhau và nó tác động đến sự phát thải khí của phương tiện vận tải. Qua đó, bài báo khẳng định tầm quan trọng của việc xây dựng chu trình lái đặc trưng trước khi tiến hành kiểm kê phát khí thải đối với nguồn động.

Tù khóa: thói quen lái, chu trình lái, hệ số phát thải, xe buýt Hà Nội, mô hình IVE. 